\title{
ПОДОБРУВАҢЕ НА ЧОВЕКОВИТЕ ПРАВА ВО ЗДРАВСТВЕНАТА ЗАШТИТА ВО РЕПУБЛИКА МАКЕДОНИЈА
}

\author{
Мухамед Таириㄹ, Фимка Тозија2,3 \\ Факулшеиеи на меgицински науки, Државен универзишеше во Теш̄ово, Реӣублика Северна Макеgонија

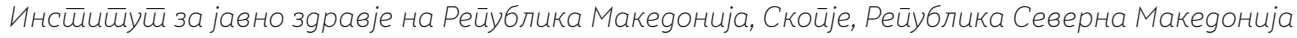

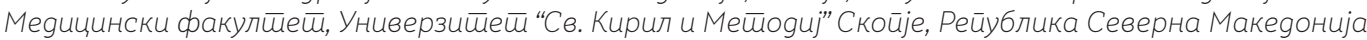

\section{Извадок}

Цитирање: Таири М, Тозија Ф. Подобрување на овековите права во здравствената заштита во Република Македонија. Арх J Здравје 2019; 11(1):6-19

Клучни зборови: човекови права, пациенти, ле гислатива, здравствена заштита, имплементација *Кореспонденција: Мухамед Таири, Факултет на медицински науки, Државен универзитет во Тетомедицински науки, Државен универзитет

Примено: 24-јан-2019; Ревидирано: 25-фев-2019; Прифатено: 28-фев-2019; Објавено: 15-мар-2019

Печатарски права: 2019 Мухамед Таири. Ова статија е со отворен пристап дистрибуирана под условите на нелокализирана лиценца, која овоз можува неограничена употреба, дистрибуција и репродукција на било кој медиум, доколку се ци тираат оригиналниот(ите) автор(и) и изворот.

Конкурентски интереси: Авторот изјавува дека нема конкурентски интереси.

Правата на пациентите произлегуваат од општите човекови права и се важен сегмент во процесот на „европеизација“ на Република Македонија. Главна цел на оваа студија беше да се анализира легислативната рамка на човековите права во здравствената заштита во Република Македонија и имплементацијата во пракса. Материјал и методи: Студијата е дизајнирана како дескриптивно-аналитичка студија на пресек, во која беше применет јавноздравствен пристап, информатичко-аналитичен метод и метод на синтеза на евиденција (evi-dence synthesis) за анализа на релевантната легислатива. Беше спроведено анкетно истражување на репрезентативен стратифициран примерок на пациенти во Полошкиот Регион, во период од два месеци, октомври-ноември во 2017 година, во Клиничката болница во Тетово и Општата болница во Гостивар. Резултати: Беше анализиран правниот систем на Република Македонија и беше спореден со 6 држави во транзиција, кои претрпеа низа суштински реформи во последниве години. Легислативната рамка во Република Македонија претставува сеопфатна рамка за заштита на правата на пациентот, со која на пациентот му се загарантирани законски права во процесот на лекувањето, почитувањето и заштитата на неговата личност и интегритет. Во овој труд имплементацијата на правата на пациентите во пракса беше анализирана преку имплементацијата на две права на пациентите, и тоа: право на информираност за препорачаните медицински интервенции и право на прифаќање и одбивање на определена медицинска интервенција. 85,2\% од анкетираните пациенти имале информации за правото на информираност за препорачаните медицински интервенции, а 14,8\% немале. 72,1\% од анкетираните пациенти имале лично искуство за ова право, додека 27,9\% немале. Во однос на правото на прифаќање и одбивање на определена медицинска интервенција, 77\% од анкетираните пациенти имале информации за ова право, а 23\% немале. Значително помало беше личното искуство за ова право, односно само 32,8\% од анкетираните пациенти имале лично искуство, а 67,2\% немале. Разликите беа сигнификантни во одговорите за двете права, и за информацијата и за личното искуство. Заклучок: Човековите права во здравствената заштита во Република Македонија се рефлектирани во националната легислатива која е хармонизирана со европската и меѓународната. Меѓутоа, потребно е подобрување на имплементацијата на правата на пациентите во пракса, преку подигнување на свеста на граѓаните за познавање на правата на пациентите и поттикнување на медицинскиот персонал за почитување на правата на пациентите и нивна задолжителна примена во пракса.

\section{PUBLIC HEALTH}

\section{IMPROVEMENT OF HUMAN RIGHTS IN PATIENT CARE IN REPUBLIC OF MACEDONIA}

\author{
Muhamed Tairi', Fimka Tozija2,3 \\ Faculty of medical science, State University in Tetovo, Republic of North Macedonia \\ Institute of public health of Republic of Macedonia, Skopje, Republic of North Macedonia \\ Medical Faculty, University Sts Ciril and Methodius, Skopje, Republic of North Macedonia
}

\section{Abstract}

Citation: Tairi M, Tozija M. Improvement of human rights in patient care in Repub-lic of Macedonia. Arch Pub Health 2019;11(1):6-19 (Macedonian)

Key words: dental caries, school children, drinking water, fluoride, DMFT index, oral epidemiology

The rights of patients are based on the general human rights and are an im-portant segment in the process of „Europeanization“ of the Republic of Macedonia. The main goal of this study was to analyze the legislative framework of human rights in the health care in the Republic of Macedonia and its implementation in practice. Material and methods: The study was designed as a descriptive-analytical cross sectional study, in which a *Correspondence: Vesna Ambarkova. Department public health approach, an information-analytical method and evidence synthesis method were applied for the for children and preventive dental medicine, Faculty for children and preventive dental medicine, Faculty of Dental Medicine, Ss. Cyril and Methodius Univesity Skopje, Republic of North Macedonia. E-mail: ambveki@yahoo.com

Received: 13-Jan-2019; Revised: 18-Feb-2019; Accepted: 28-Feb-2019; Published: 15-Mar-2019

Copyright: ${ }^{\odot}$ 2019. Konstandina Kuzevska-Maneva. This is an open-access article distributed under the terms of the Creative Commons Attribution License which permits unrestricted use, distribution, an reproduction in any medium, provided the origina author(s) and source are credited.

Competing Interests: The author have declared that no competing interests analysis of the relevant legislation. A survey was conducted on a representative stratified sample of patients in the Polog Region in the period from October to November 2017 in the Clinical Hospi-tal Tetovo and the General Hospital Gostivar. Results: The legal system of the Republic of Macedonia was analyzed and compared with 6 transition countries, which had undergone a series of substantial reforms in recent years. The legislative framework in the Republic of Macedonia is a compre-hensive frame for protection of patients' rights, with which the patient is guaranteed legal rights in the process of treatment, respect and protection of his/her personality and integrity. The implementation of patients rights in practice in this paper was analyzed by implementation of two rights of pa-tients: the right on information about the recommended medical interventions and the right to accept and reject certain medical intervention. $85.2 \%$ of the interviewed patients had information on the right to information about the recommended medical interventions, and $14.8 \%$ didn't have. $72.1 \%$ of the interviewed patients had personal experience for this right, and 27.9\% didn't have. Regarding the right to accept and reject certain medical interven-tion, $77 \%$ of the interviewed patients had information on this right, while 23\% didn't have. Personal experience was significantly smaller with this right, i.e. only 32.8\% of the interviewed patients had personal experience, and 67.2\% didn't have. These differences were significant for both rights, for information and for personal experience. Conclusions: The human rights in the health care in the Republic of Macedonia are reflected in the national legislation, which is harmonized with the European and international legisla-tion. However, it is necessary to improve the implementation of patients" rights in practice by raising the citizens' awareness about the knowledge of patients' rights and encouraging medical staff to respect the rights of patients and their compulsory application in practice. 


\section{Вовед}

Човековите права се највисок дострел во развојот на вредносниот систем на човекот; тие претставуваат сублимација на хуманата димензија на сите претходни учења (религиозни, филозофски, правни) и мерило на достигнатиот развој на човештвото. Статутот на Светската здравствена организација (СЗО) од 1948 година нагласува дека „уживањето на највисок можен стандард на здравје е едно од фундаменталните права на секое човечко суштество, без оглед на расна или верска припадност, политичко убедување, економска или општествена состојба“".

Правата на пациентите произлегуваат од овие општи права и се важен сегмент во процесот на ,,европеизација“ на Република Македонијаㄹ․ Начелата за заштита на правата на пациентите во Република Македонија се засноваат врз начелата за здравствена заштита дефинирани во законот за здравствена заштита 3 .

Специфичните права на пациентите се дефинирани во регионалните и меѓународните инструменти (на пр. Европската повелба за права на пациенти, Декларацијата за промоција на права на пациенти во Европа од страна на СЗО) како и во национални повелби и законодавство ${ }^{4}$

Меѓународната рамка за правата на човекот ја опфаќа Универзалната декларација за човекови права ${ }^{5}$ и девет меѓународни договори што содржат меѓународни стандарди во однос на почитување, промовирање и заштита на човековите права. Овие договори се обврзувачки за државите кои ги ратификувале. Со регионалната рамка се уредуваат главните стандарди што ги штитат човековите права во здравствената заштита во Европа (како што е географски дефинирана од страна на Советот на Европа) и се проверува како тие се толкувани од супранационалните тела, најмногу од Европскиот суд за човековите права и од Европскиот комитет за социјалните права.

Здравствениот систем, здравствената заштита и правата и обврските на здравствените работници, установи и пациенти во Република Македонија се регулирани со низа законски прописи. Правото на здравје и здравствена заштита е загарантирано со Уставот на Република Македонија според кој „на секој граѓанин му се гарантира правото на здравствена заштита“ и „граѓанинот има право и должност да го чува и унапредува сопственото здравје и здравјето на другите“6. Во согласност со уставните одредби, донесени се повеќе закони, меѓу кои: законот за здравствена зашти$\mathrm{Ta}^{3}$, законот за заштита на правата на пациентите ${ }^{7}$, законот за здравствено осигурување ${ }^{8}$, законот за јавно здравје $\mathrm{e}^{9}$, законот за менталното здравје ${ }^{10}$ и други закони кои потесно регулираат определена област од здравството.

Правата на пациентите во здравствената заштита се регулирани со Законот за заштита на правата на пациентите, донесен на 08.07.2008 година7. Со овој закон подетално се уредуваат заштитата на правата на пациентите во користењето на здравствената заштита; должностите на здравствените установи и здравствените работници и соработници во обезбедување на здравствената заштита; надлежностите на општините и Фондот за здравственото осигурување во однос на унапредување и заштита на правата на пациентите; постапката за заштита на правата на пациентите и надзорот над спроведувањето на законот.

Секој граѓанин има право да ја остварува здравствената заштита со почитување на највисокиот можен стандард на човековите права и вредности, односно има право на физички и психички интегритет и на безбедност на неговата личност, како и на почитување на неговите морални, културни, религиозни и филозофски убедувања. Секој граѓанин има право на информации потребни за зачувување на здравјето и стекнување здрави животни стилови и на информации за штетните фактори за животната и работната средина кои можат негативно да влијаат на здравјето, како и на информации за потребните мерки за заштита на здравјето во случаи на појава на епидемии и други непогоди и несреќи кои можат негативно да влијаат на здравјето 3 .

Здравствената заштита се заснова врз единството на превентивните, дијагностичко-терапевтските и рехабилитационите мерки и врз начелата на достапност, ефикасност, континуираност, правичност, сеопфатност и обезбеду- 
вање на квалитетен и сигурен здравствен третман ${ }^{3,7}$.

Република Македонија како земја кандидат за влез во Европската Унија својата законска регулатива мора да ја приспособи на европската, со тоа што во сите сегменти од човековото живеење и општествување ќе има законска рамка која ќе ги гарантира основните права на човекот вклучувајќи ги и правата на пациентите.

Главна цел на истражувањето беше да се анализира легислативната рамка на човековите права во здравствената заштита во Република Македонија и нејзината имплементација во пракса.

\section{Материјал и методи}

Студијата е дизајнирана како дескриптивно-аналитична студија на пресек, во која се истражуваат човековите права во здравствената заштита, легислативната рамка и нејзината имплементација во пракса.

Во студијата беше применет јавноздравствен пристап и информатичко-аналитички метод за анализа на меѓународната, регионалната и легислативната рамка за човековите права во здравсвената заштита во Република Македонија и за споредба на националната легислатива со Европската легислатива за правата на пациентите и здравствените работници. Податоците за овој дел од истражувањето се собрани преку синтеза на евиденција (evidence synthesis), методологија на документи од релевантните легислативни рамки во здравствената заштита, кои се предмет на истражување, како и публикации и друг документиран материјал. Беа анализирани Уставот, закони, правилници, и други национални легислативни документи, Европската повелба за правата на пациентите и други меѓународни документи. Беше направен преглед на литературата и на објавени наоди од релевантни истражувања и студии, како и објавени публикации.

Имплементацијата на легислативната рамка во здравствената заштита беше анализирана преку анкетно истражување кое беше спроведено на репрезентативен примерок на пациенти во Полошкиот Регион, во период од два ме- сеци, октомври-ноември во 2017 година, во Клиничката болница во Тетово и во Општата болница во Гостивар. Големината на примерокот во истражувањето беше одредена со користење на статистичка програма за одредување на големината на истражувачката популација PEPI 4.04x (со моќност на истражувањето од 80\%, интервал на доверба од 95\% и максимум прифатлива грешка од 0,05 ). Анкетното истражување за правата на пациентите беше спроведено на репрезентативен примерок од 200 пациенти, што претставува 10\% од пациентите кои беа лекувани во период од два месеци во овие болници во 2017 г. Примерокот беше стратифициран по болници, и тоа 130 пациенти во Клиничката болница во Тетово и 70 пациенти во Општата болница во Гостивар, односно стратифициран и по болнички одделенија во секоја болница. Во овој труд прикажани се првичните резултати од анкетното истражување со податоци од 61 пациент. Анкетното истражување на пациентите беше спроведено со специјално дизајниран инструмент - анкетен прашалник за пациенти, дизајниран согласно Европската и националната легислатива за правата на пациентите, кој се состои од прашања за информираноста на пациентите за нивните права во здравствена заштита, но, исто така и за нивната имплементација во пракса.

Во истражувањето беа вклучени пациенти на возраст над 18 години, кои сакаа и беа способни да го одговорат анкетниот прашалник за пациенти. Од истражувањето беа исклучени пациенти на возраст под 18 години, кои не сакаа и не беа способни да го одговорат анкетниот прашалник за пациенти.

Сите податоци добиени со инструментот на истражување беа внесени во специјално изработена база на податоци. Статистичката обработка беше извршена со користење на софтверот SPSS 16.0. За анализа на податоците беа употребени стандардни статистички методи со примена на барана статистичка сигнификантност за $\mathrm{p}<0,05$ (резултати кои се сметаат за статистички значајни), а резултатите со вредност за р>0,05 како „отсуство на евиденција за статистичка значајност“. Резултатите од квантитативното истражување прикажани се табеларно и графички. 


\section{Резултати}

\section{Синтеза на евиденција на легислатив- ната рамка}

Легислативата за човекови права на меѓународно, регионално и национално ниво обезбедува важна формална и процедурална рамка за справување со злоупотреба на човековите права во грижата за пациентот.

Европската повелба за правата на пациентите $^{4}$ дава јасна, сеопфатна рамка за правата на пациентите. Оваа формулација на правата е дел од едно граѓанско движење низ Европа, во кое се повикуваат пациентите да играат поактивна улога во пружањето на здравствените услуги ${ }^{11}$ и пренесувањето на регионалните документи за правото на здравствена заштита во конкретни одредби ${ }^{12}$. Европската повелба ги систематизира правата на пациентите во четиринаесет конкретни одредби. Оваа повелба претставува корисна законска рамка за примена на општите принципи за човекови права во конкретниот контекст на грижата за пациентот (види табела 1).

Во рамките на Обединетите нации, голем број главни обврзувачки договори и договори содржат важечки одредби ${ }^{13}$.
Тие вклучуваат различни инструменти на ЕУ, како што се Европската конвенција за човекови права и Европската социјална повелба, и други релевантни документи за грижа за пациентот ${ }^{14,15}$.

Европската повелба ${ }^{4}$ ги дефинира следните 14 права на пациентите: право на превентивни мерки, право на пристап, право на информации, право на согласност, право на слободен избор, право на приватност и доверливост, право на почитување на времето на пациентот, право на почитување на стандардите за квалитет, право на безбедност, право на иновација, право на избегнување непотребно страдање и болка, право на персонализирано лекување, право на жалба и право на надомест.

Меѓународната рамка дефинира девет најважни права на пациентите: право на слобода и на безбедност на личноста, приватност и доверливост, информираност, физички интегритет, живот, највисок степен на здравје што може да се постигне, слобода од тортура, сурово, нечовечно и понижувачко постапување, учество во јавните политики и недискриминација и право на еднаквост на пациентите ${ }^{5}$.

табела 1. Права на пациентите - меѓународна и европска рамка

\begin{tabular}{|l|l|}
\hline Европска повелба за права на пациенти & Меѓународна рамка на човекови права \\
\hline Право на превентивни мерки & Право на здравје \\
\hline Право на пристап & Право на недискриминација и еднаквост \\
\hline Право на информација & Право на информација \\
\hline Право на согласност & $\begin{array}{l}\text { Право на телесен интегритет: право на слобода и безбедност } \\
\text { на лицето, право на слобода од тортура и суров, нечовечен и } \\
\text { деградирачки третман, право на приватност и право на здравје }\end{array}$ \\
\hline Право на слободен избор & $\begin{array}{l}\text { Право на телесен интегритет: право на слобода и безбедност } \\
\text { на лицето, право на слобода од тортура и суров, нечовечен и } \\
\text { деградирачки третман, право на приватност ираво на здравје }\end{array}$ \\
\hline Право на приватност и доверливост & Право на приватност \\
\hline $\begin{array}{l}\text { Право на почитување на времето на } \\
\text { пациентот }\end{array}$ & Право на здравје \\
\hline $\begin{array}{l}\text { Право на почитување на } \\
\text { стандардите за квалитет }\end{array}$ & Право на здравје, право на живот \\
\hline Право на безбедност & Право на здравје, право на живот \\
\hline Право на иновации & Право на здравје, право на корист од научниот напредок \\
\hline $\begin{array}{l}\text { Право да се избегнат непотребни } \\
\text { болки и страдања }\end{array}$ & $\begin{array}{l}\text { Право на здравје, право на слобода од тортура и суров, } \\
\text { нечовечен и деградирачки третман }\end{array}$ \\
\hline $\begin{array}{l}\text { Право на персонализиран третман } \\
\text { Право на здравје, право на недискриминација и } \\
\text { еднаквост }\end{array}$ \\
\hline Право на жалба, право на надомест & Право на лек \\
\hline
\end{tabular}

Извор: Advancing Human Rights in Patient Care: The Law in Seven Transitional Countries ${ }^{11}$ 
Интернационалниот и европскиот режим за човекови права ги користи индивидуалните тела за мониторинг, судовите и другите посебни процедури за да ги спроведе своите одредби. Во рамките на многуте договори и инструменти кои го сочинуваат меѓународниот систем за човекови права, постојат голем број одредби кои можат да се применуваат и во контекст на грижата за пациентот. Примарно меѓу нив е правото на највисок достапен стандард на здравје, вклучувајќи и спроведување на ефективни мерки за превенција, лекување и контрола на болеста ${ }^{16,17,18,}$ 19,20 .

Човековите права во здравствената заштита е правна област која во Република Македонија е соодветно работена и во националното законодавство и со ратификуваните и потпишани меѓународни инструменти. Уште од осамостојувањето правото на здравје и обврската за грижа за сопственото и здравјето на другите е инкорпорирано во Уставот на PM6 и во позитивните прописи, а од тогаш и развиено со права и обврски како на пациентите така и на здравствените работници и здравствените установи. Легислативната рамка во Република Македонија опфаќа една целина во сферата на заштита на правата на пациентот, каде што на пациентот му се загарантирани законски права во процесот на лекувањето кои ќе му обезбедат почитување и заштита на неговата личност и интегритет и оваа рамка е хармонизирана со европската легислатива $^{3}$.

Законот за заштита на правата на пациентите ${ }^{7}$ ги уредува заштитата и правата на пациентите при користење на здравствена заштита, како и должностите на здравствените установи и здравствени работници и соработници, општините и фондот за здравствено осигурување во заштитата и унапредувањето на правата на пациентите. Со ова се обезбедува квалитетна и континуирана здравствена заштита во согласност со достигнувањето во здравството и медицината во рамките на системот за здравствена заштита и здравствено осигурување, поединечните потреби на пациентот, без психичка и физичка злоупотреба и целосно почитување на личноста на пациентот во негов најдобар интерес.

Следните права на пациентите се дефинирани со Законот за заштита на правата на пациентите: право на учество во одлучувањето, право на информираност, право на одбивање на прием на информација, право на прифаќање и одбивање на определена медицинска интервенција, без писмена согласност на пациентот, тој/таа не може да биде вклучен во научно истражување и во медицинска настава, право на увид во медицинското досие, право на доверливост (тајност, право на професионални контакти, право на самоволно напуштање на здравствената установа, право на приватност) ${ }^{7}$.

\section{Имплементација на националната легислативата во пракса}

Во овој труд се презентирани првичните резултати од истражувањето, односно податоците од анкетираните 61 пациент, во Клиничката болница во Тетово $(63,9 \%)$ и Општата болница во Гостивар (36,1\%), за имплементацијата во пракса на две права на пациенти, и тоа: право на информираност за препорачаните медицински интервенции и право на прифаќање и одбивање на определена медицинска интервенција. Пациентите беа анкетирани од повеќе одделенија, а најмногу од гинеколошко-акушерското $(42,6 \%), 24,6 \%$ беа од хируршкото, 21,3\% од интерното одделение итн. Повеќето од анкетираните пациенти беа на возраст од 30 до 39 години (36,1\%), а просечната возраст изнесуваше 42,2 $\pm 16,3$ години, во опсег од 19 годни до 86 години. 62,3\% од анкетираните беа Албанци, 26,2\% Македонци, а 73,8\% беа припадници на муслиманската вероисповест, 19,7\% православни христијани итн. (види табела 2). 
табела 2. Демографски карактеристики на анкетираните пациенти

\begin{tabular}{|c|c|c|c|}
\hline Варијабла & Број & $\%$ & Difference test $p$ \\
\hline \multicolumn{4}{|l|}{ Здравствена установа } \\
\hline Гостивар & 22 & 36,1 & $<0,05$ \\
\hline Тетово & 39 & 63,9 & \\
\hline \multicolumn{4}{|l|}{ Одделение } \\
\hline интерно & 13 & 21,3 & \\
\hline хирургија & 15 & 24,6 & \\
\hline гинекологија & 26 & 42,6 & $<0,05$ \\
\hline нервни болести & 5 & 8,2 & \\
\hline ортопедија & 1 & 1,6 & \\
\hline ORL & 1 & 1.6 & \\
\hline \multicolumn{4}{|l|}{ Возраст } \\
\hline $18-19$ & 3 & 4,9 & \\
\hline $20-29$ & 10 & 16,4 & \\
\hline $30-39$ & 22 & 36,1 & \\
\hline $40-49$ & 7 & 11,5 & $<0,05$ \\
\hline $50-59$ & 8 & 13,1 & \\
\hline $60-69$ & 7 & $\begin{array}{l}10,1 \\
11,5\end{array}$ & \\
\hline$>70$ & 4 & 6,5 & \\
\hline \multicolumn{4}{|l|}{ Пол } \\
\hline Мажи & 18 & 29,5 & $<0,05$ \\
\hline Жени & 43 & 70,5 & \\
\hline \multicolumn{4}{|l|}{ Националност } \\
\hline Албанци & 38 & 62,3 & \\
\hline Роми & 5 & 8,2 & $<0,05$ \\
\hline Македонци & 16 & 26,2 & \\
\hline Турци & 2 & 3,3 & \\
\hline \multicolumn{4}{|l|}{ Вероисповест } \\
\hline муслимани & 45 & 73,8 & \\
\hline православни & 12 & 19,7 & $<0,05$ \\
\hline католици & 4 & 6,5 & \\
\hline \multicolumn{4}{|l|}{ Образование } \\
\hline $6 е 3$ & 3 & 4,9 & \\
\hline до IV одделение & 4 & 6,6 & \\
\hline OCHOBHO & 15 & 24,6 & \\
\hline средно & 19 & 31,1 & \\
\hline више & 3 & 4,9 & $>0,05$ \\
\hline Високо & 16 & 26,2 & \\
\hline доктор на науки & 1 & 1,6 & \\
\hline \multicolumn{4}{|l|}{ Работен статус } \\
\hline пензионер & 7 & 11,5 & \\
\hline вработен & 31 & 50,8 & $>0,05$ \\
\hline социјална помош & 1 & 1,6 & \\
\hline невработен & 22 & 36,1 & \\
\hline \multicolumn{4}{|l|}{ Брачна состојба } \\
\hline во брак & 46 & 74,4 & \\
\hline вдовец/вдовица & 6 & 9,78 & $<0,05$ \\
\hline вонбрачна заедница & 5 & 8,2 & \\
\hline неженет/немажена & 4 & 6,6 & \\
\hline
\end{tabular}

31,1\% од анкетираните пациенти беа со средна стручна подготовка, 27,8\% со високо образование (еден е доктор на науки), 24,6\% беа со основно училиште итн. Повеќе од половината анкетирани (50,8\%) беа вработени, невработени беа 36,1\%, пензионери 11,5\% итн.
Од вкупниот број анкетирани, 29,5\% беа припадници на машкиот пол со просечна возраст од 50,2 \pm 19,6 години. 70,5\% беа припадници на женскиот пол со просечна возраст од 38,9 13,6 години. Разликата во однос на просечната возраст беше статистички сигнификантна за $\mathrm{p}<0,05$ (t-test $=2,574630, p=0,012564)$ (графикон 1). 


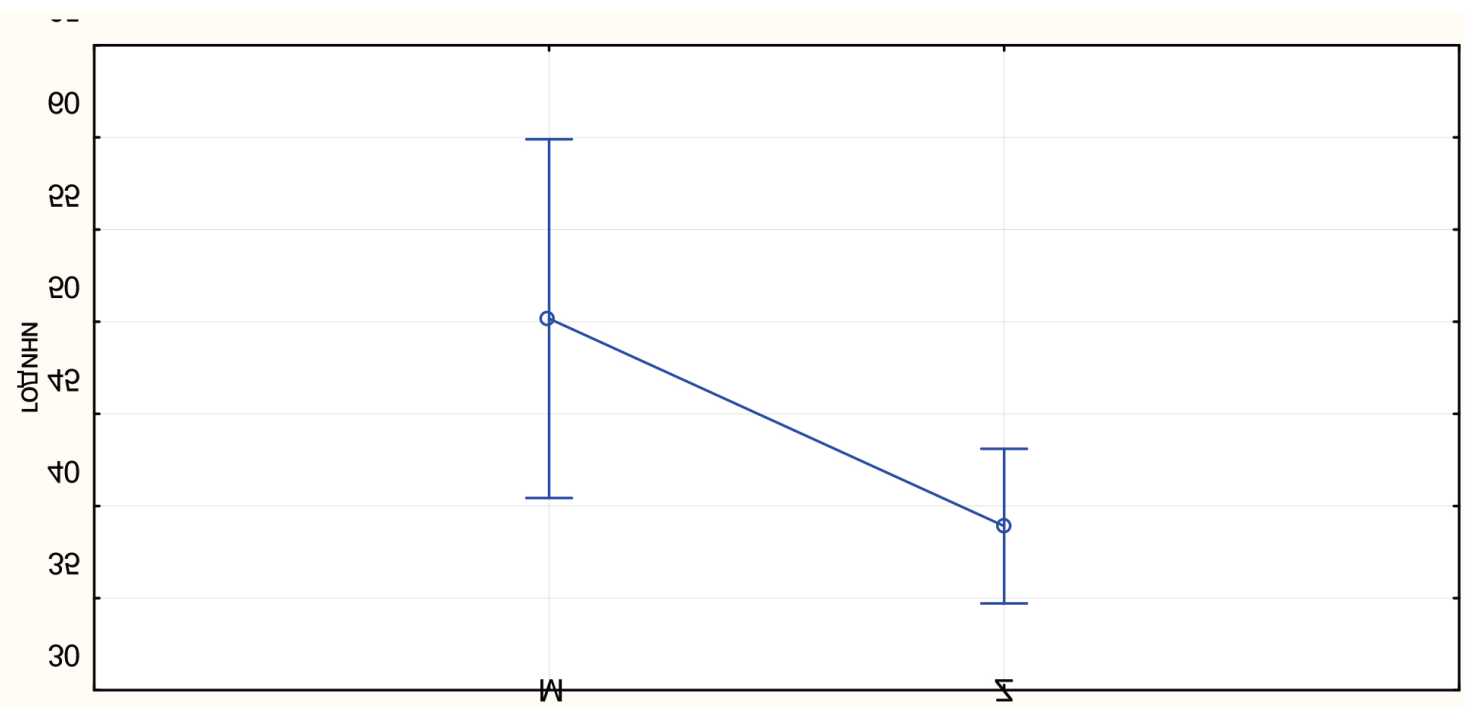

Графикон 1. Просечна возраст на анкетираните пациенти

85,2\% од анкетираните пациенти имале информации за правото на информираност за препорачани медицински интервенции, а 14,8\% немале. Оваа раз- лика беше статистички сигнификантна за $\mathrm{p}<0,05$ (Difference test, $\mathrm{p}=0,0000)$ (графикон 2).

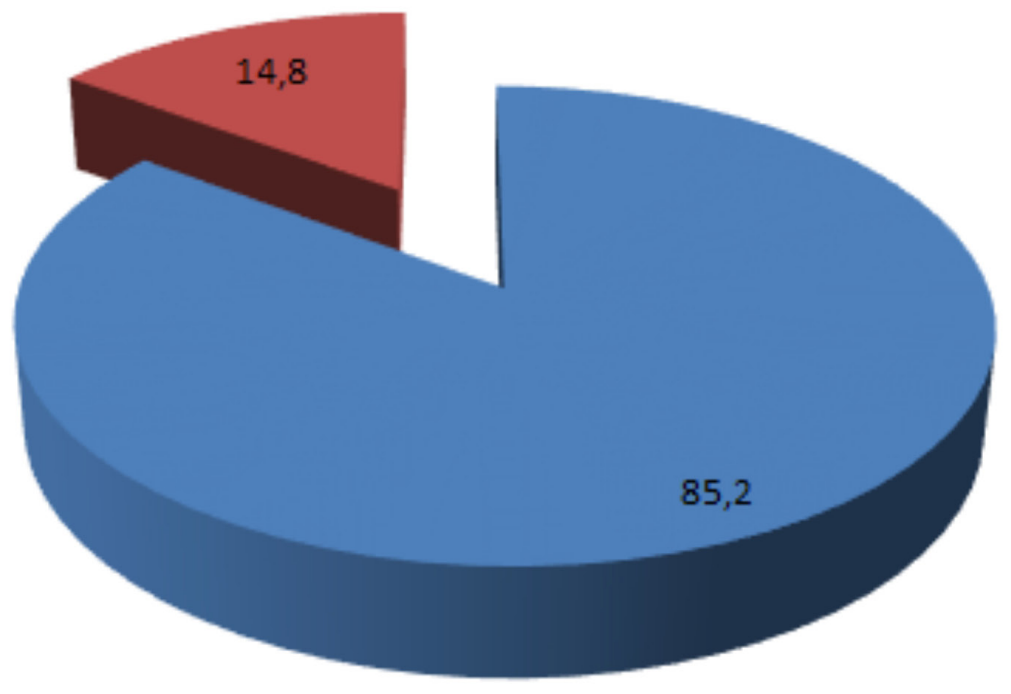

Графикон 2. Информации за Право на информираност за препорачани медицински интервенции

Не беше регистрира поврзаност помеѓу одговорот на анкетираните пациенти и: градот каде беше извршена анкетата (Pearson Chisquare: 1,73926, p=,187233); полот на анкетираните (Pearson Chi-square: 1,13232, $p=, 287280$ ); етничката припадност (Pearson Chi-square: 1,68244, $\mathrm{p}=, 640845)$; вероисповеста (Pearson Chi-square: ,750190, p=,687224); степенот на образование (Pearson Chi-square: 6,71972, $\mathrm{p}=$,347546); работниот статус (Pearson Chisquare: $3,50703, p=, 319852)$ и брачниот статус
(Pearson Chi-square: 6,35996, $\mathrm{p}=, 384098$ ).

72,1\% од анкетираните имале лично искуство со примена на правото за препорачани медицински интервенции, а 27,9\% немале (графикон 3). Процентуалната разлика беше статистички сигнификантна за $\mathrm{p}<0,05$ (Difference test, $\mathrm{p}=0,0000)$. Не се регистрира поврзаност помеѓу градот каде беше извршена анкетата и одговорот на анкетираните пациенти (Pearson Chi-square: 1,23524, $\mathrm{p}=, 266391)$. 


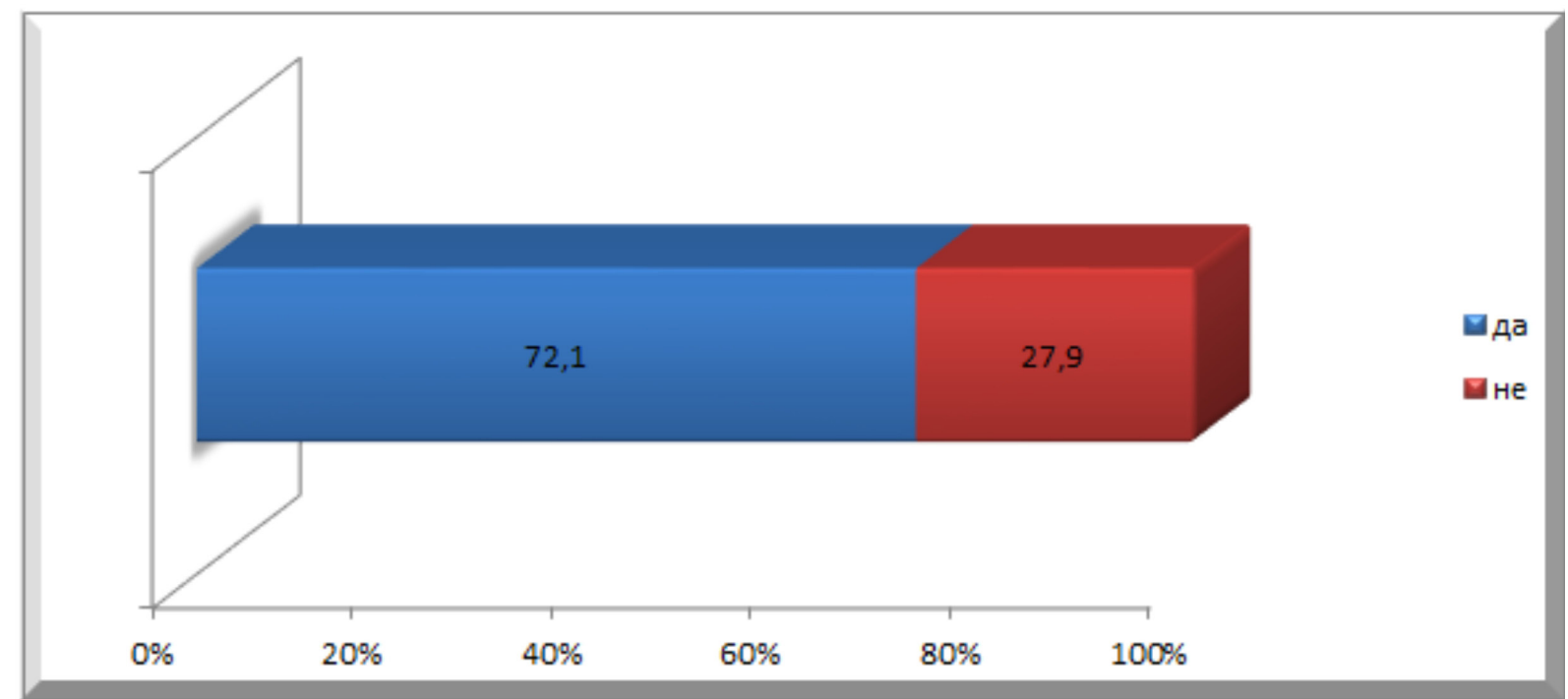

Графикон 3. Лично искуство со Право на информираност за препорачани медицински интервенции

Не беше регистрирана поврзаност помеѓу полот на анкетираните и одговорот на анкетираните пациенти (Pearson Chi-square: ,379306, p=,537975), ниту, пак, поврзаност со: етничката припадност (Pearson Chi-square: 7,13033, p=,067858); вероисповеста (Pearson Chi-square: 2,96301, $\mathrm{p}=, 227295) ;$ степенот на образование (Pearson Chi-square: 6,40596, $\mathrm{p}=, 379282$ ); работниот статус (Pearson Chi-square: 4,41732, p=,219784); брачниот статус (Pearson Chi-square: 3,01829, $\mathrm{p}=, 806548)$.
77,0\% од анкетираните пациенти имале информација за правото на прифаќање и одбивање на определена медицинска интервенција, а 23,0\% немале (графикон 4). Процентуалната разлика беше статистички сигнификантна за $\mathrm{p}<0,05$ (Difference test, $\mathrm{p}=0,0000$ ). Ce регистрира поврзаност помеѓу градот каде беше извршена анкетата и одговорот на анкетираните пациенти (Pearson Chi-square: 14,2374, p=,000161).

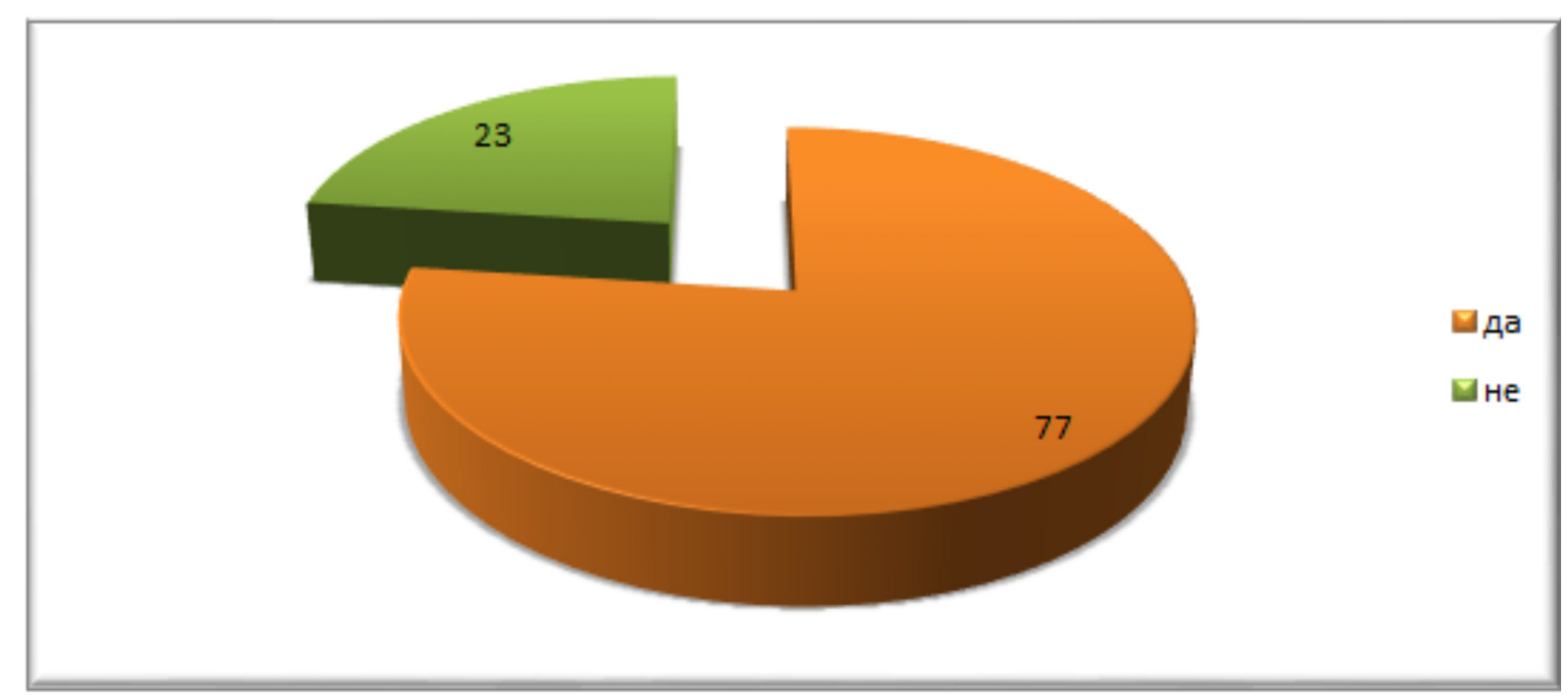

Графикон 4. Информација за Право на прифаќање и одбивање на определена медицинска интервенција

Не беше регистрира поврзаност помеѓу одговорот на анкетираните пациенти и следните варијабли на анкетираните пациенти: пол (Pearson Chi-square:
,007666, p=,930232), етничка припадност (Pearson Chi-square: 1,02336, $\mathrm{p}=, 795601$ ), вероисповест (Pearson Chisquare: ,334254, p=,846092), степен на 
образование на анкетираните (Pearson Chi-square: 13,1933, $\mathrm{p}=, 047794)$, pa6oтен статус (Pearson Chi-square: 3,03195, $\mathrm{p}=, 386726)$ ), брачен статус (Pearson Chisquare: 8,75394, $\mathrm{df}=6, \mathrm{p}=, 187896)$.

$32,8 \%$ од анкетираните пациенти имале лично искуство со примена на правото за прифаќање или одбивање на медицинска интервенција, а 27,9\% немале (графикон 5). Процентуалната разлика беше статистички сигнификантна за $\mathrm{p}<0,05$ (Difference test, $\mathrm{p}=0,0001$ ). Ce peгистрира поврзаност помеѓу полот на анкетираните и одговорот на анкетираните пациенти (Pearson Chi-square:

\subsection{4, $\mathrm{p}=.019634)$.}

Не беше регистрирана поврзаност помеѓу одговорот на анкетираните пациенти и следните варијабли: град(Pearson Chi-square: ,199761, df=1, p=,654914), етничка припадност (Pearson Chi-square: ,802436, $\mathrm{p}=$,848884). вероисповест (Pearson Chi-square: 3,62198, $\mathrm{p}=, 163492$ ), степен на образование, (Pearson Chisquare: 7,06481, $\mathrm{p}=, 314896)$, работен статус (Pearson Chi-square: 5,32492, $\mathrm{df}=3$, $\mathrm{p}=, 149494)$ и брачен статус (Pearson Chisquare: 7,80684, $\mathrm{p}=, 252599)$.

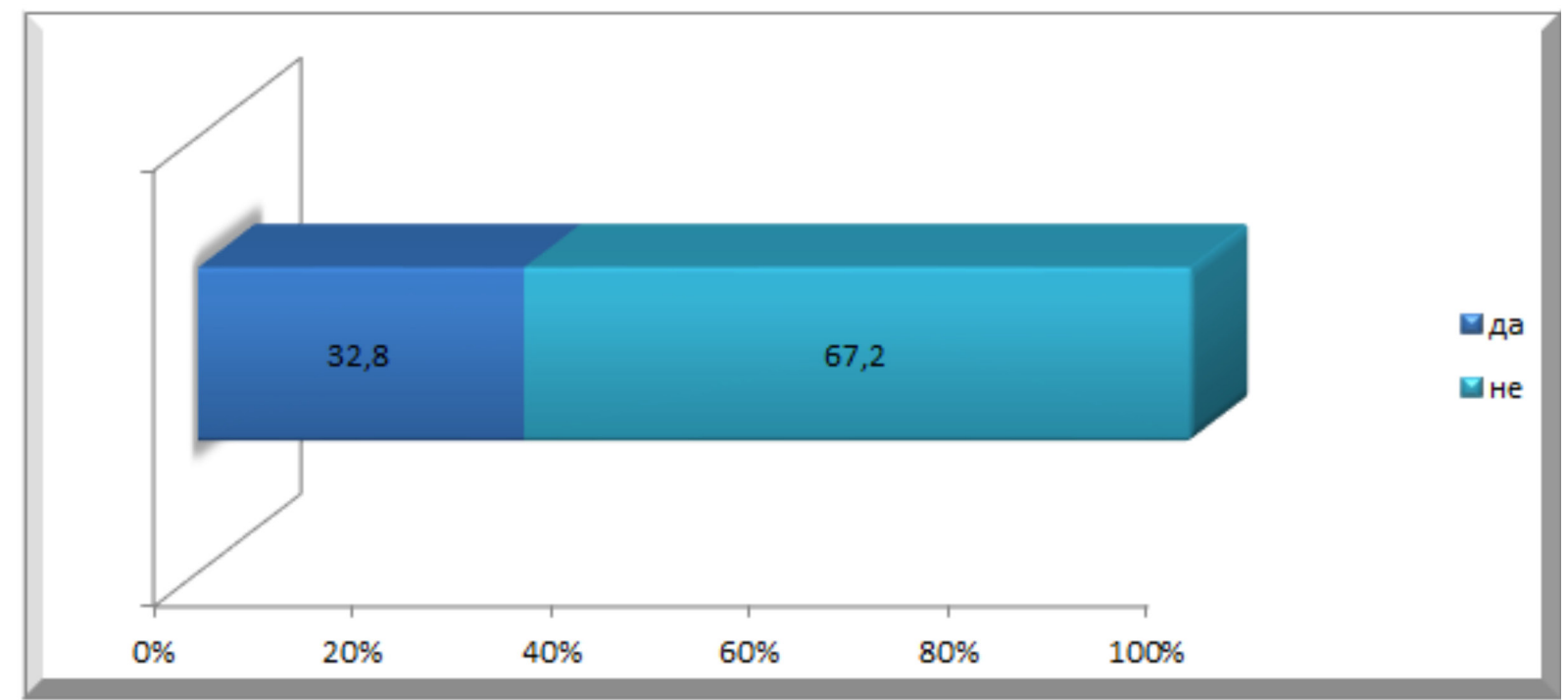

Графикон 5. Лично искуство со примена на Право на прифаќање и одбивање на определена медицинска интервенција

\section{Дискусија}

\section{Политички контекст, здравствен сис- тем и регулатива}

Република Македонија по осамостојувањето наследи високо децентрализиран, високо автономен, социјалистички здравствен систем, со финансирање и контрола првенствено на локално ниво. Поради фрагментацијата на пружањето услуги и дуплирање на услугите и објектите, се премина во систем на задолжително здравствено осигурување со централно управување по независноста, со движење повторно кон децентрализација ${ }^{21}$. Системот на здравствена заштита на новата независна ре- публика се соочи со предизвици и потреба за надминување на проблемите од поранешниот здравствен систем и обезбедување стабилно финансирање ${ }^{22}$. По 2006 година, владината политика за сеопфатни здравствени реформи е насочена кон со цел намалување на нееднаквостите за здравје и обезбедување услуги според потребите на пациентите $^{23}$. Во 2012 година, за Владата на Република Македонија, главни приоритети за здравствениот систем до 2015 година беа: подигнување на квалитетот на здравствените услуги, зајакнување на примарната здравствена заштита и превенција, и воспоставување стабилен систем за финансирање на здравствената заштита на сите граѓани ${ }^{24}$.

Повеќето од државите во транзиција направиле значителни чекори 
за усогласување на нивните развојни законски режими со меѓународните стандарди. Ерменија, Грузија, Русија и Украина, членки на Советот на Европа, го сторија тоа и во однос на европските стандарди. (Во 2009 година, Ерменија, Грузија и Украина се приклучија на Источното партнерство, проект инициран од Европската унија.) Казахстан и Киргистан спроведоа големи здравствени реформи ${ }^{11}$. Република Македонија, покрај членството во Советот на Европа, дополнително ги усогласува своите закони и стана официјална земја - кандидат за пристап во ЕУ во 2005 година; Пристапниот дијалог на високо ниво со Европската унија започна во март 2012 година ${ }^{25}$. Македонија е ангажирана во континуиран процес на реформи поврзани со пристапување, вклучувајќи реорганизација за да ги пополни структурните јазови и мерките за зајакнување на судската независност, иако се потребни понатамошни чекори за подобрување на независноста и професионалноста, како и за борба против корупцијата ${ }^{26}$.

Законодавната рамка за регулирање на здравствениот сектор варира помеѓу земјите. Во неколку земји, вклучувајќи ги Украина, Грузија, Русија и Казахстан, кои произлегуваат од уставното обезбедување на правото на здравје, законот за здравствена заштита генерално ги дефинира регулирањето, сопственоста, финансирањето и други прашања. Многу од овие земји исто така донесоа закони и прописи кои регулираат одредени аспекти на здравствениот сектор. На пример, Казахстан, Грузија, Русија, Украина, Македонија, Ерменија и Киргистан имаат закони со кои се регулираат здравствените и фармацевтските професии. Во сите земји постојат закони со кои се регулира финансирањето на здравствената заштита. Дополнително, во сите седум земји постојат закони со кои се регулира врската помеѓу државата и другите субјекти вклучени во активностите за здравствена заштита11. Меѓу 7-те земји во транзиција, Ерменија, Грузија, Казакистан, Киргистан, Русија и Украина, Македониаја се истакнува со хармонизација на легислативата за подобрување на здравствениот систем и особено за подобрување на правата на пациентите ${ }^{27}$.
Една од активностите на државите во процесот на подготовки за пристапување во Европската Унија е хармонизирање на националната легислатива за здравствена заштита со европските стандарди ${ }^{28}$. Многу земји, како што е Бугарија, усвоиле нов закон за здравство, чија структура и содржина се стриктно во согласност со Европската повелба за правата на пациентите.

Иако Европската повелба не е правно обврзувачка, силна мрежа на групи за правата на пациентите ширум Европа успешно ги лобираа нивните национални влади за признавање и усвојување на правата што ги адресира ${ }^{11}$. Слични повелби за правата на пациентите се развиени во други региони и земји ${ }^{12}$. Повелбата исто така се користи како референца за следење и оценување на системите за здравствена заштита низ цела Европа, и е една од најсеопфатните, неодамнешни и широко распространети изрази на правата на пациентите. Поради овие причини, Повелбата е избрана како концептуална организациска рамка за анализа во оваа студија.

Повелбата, исто така, се користи како основа за мониторинг и евалуација на здравствените системи ширум Европа, во однос на правата на пациентите. Во септември 2007 година, Европскиот економски и социјален комитет го одобри своето иницијално мислење за правата на пациентите, изјавувајќи дека „ја поздравува и ја признава Европската повелба за права на пациентите“.

Споредбата помеѓу правата на пациентите во Република Македонија и правата на пациентите во Европската повелба покажува дека во националната законска рамка се застапени сите права на пациентите кои се содржани во Европската повелба ${ }^{29}$. Меѓутоа, наодите од одредени истражувања за степенот на формирање и функционирање на законски предвидените механизми за заштита на правата на пациентите укажуваат на евидентна стагнација во спроведувањето на Законот за заштита на правата на пациентите ${ }^{30}$.

Во овој труд анализирана е националната легислативната рамка за човековите права во здравствената заштита во Република Македонија и нејзината имплементација во пракса. 
Право на информираност - Согласно Меѓународниот пакт за граѓанските и политичките права ${ }^{31}$ : „Секое лице има право на слобода на изразување. Ова право, без оглед на границите, ја подразбира слободата на наоѓање, примање и ширење информации и секаков вид идеи во усна, писмена, печатена или уметничка форма или на кој и да е начин по слободен избор”. Право на физички интегритет - Правото на физички интегритет не е посебно пропишано со Меѓународниот пакт за граѓанските и политичките права или со Меѓународниот пакт за економските, социјалните и културните права, но толкувањето е дека тоа припаѓа под правото на безбедност на лицето (член 9 од Меѓународниот пакт за граѓанските и политичките права), правото на слобода од тортура и сурово, нечовечно или понижувачко постапување (член 7 од Меѓународниот пакт за граѓанските и политичките права), правото на приватност (член 17 од Меѓународниот пакт за граѓанските и политичките права) и правото на највисок степен на здравје што може да се постигне (член 12 од Меѓународниот пакт за економските, социјалните и културните права) $)^{11}$.

Согласно Повелбата за правото на здравје ${ }^{32}$ : „Пред секој медицински третман мора да се побара согласност од пациентот, освен во итни случаи пропишани со закон".

Принципите од Декларацијата за правата на пациентите на Светската лекарска асоцијација ${ }^{33}$ ги дефинираат следните права:

Принципот број 3 - Право на самоопределување

- Пациентот има право на самоопределување, слободно да донесува одлуки што се однесуваат на неговото здравје. Лекарот ќе го информира пациентот за последиците од неговите одлуки.

- Пациентот има право да одбие да биде дел од научно истражување или настава.

Право на учество во одлучувањето го опфаќа правото на информираност и правото на прифаќање или одбивање на определена медицинска интервенција.
Ова право може да биде ограничено само кога тоа е оправдано со здравствената состојба на пациентот, во случаи и на начин уреден со Законот ${ }^{7}$

Право на информираност - Согласно законот за права на пациентите ${ }^{7}$, пациентот има право да биде потполно информиран, на разбирлив и соодветен начин, за здравствената состојба, препорачаните медицински интервенции, можните предности и ризици при спроведувањето, односно неспроведувањето на препорачаните медицински интервенции, право на одлучување за препорачаните медицински интервенции; можните замени за препорачаните медицински интервенции; причините за евентуалните разлики на постигнатиот резултат од медицинските интервенции во однос на очекуваниот; текот на постапката при укажувањето на здравствената заштита; препорачаниот начин на живеење; правата од здравствената заштита и здравствено осигурување и имињата, стручната подготовка и специјализацијата на здравствените работници кои непосредно укажуваат здравствена заштита (преку задолжително јавно истакнување на лиценцата за работа).

Пациентот секогаш има право да побара второ стручно мислење за здравствената состојба. Ова право може да го оствари со поднесување на усно или писмено барање, а секој здравствен работник со најмалку иста стручна подготовка како на здравствениот работник кој го дал првото мислење има обврска да даде мислење.

Право на одбивање на прием на информација - Пациентот, со писмена потпишана изјава, има право да одбие прием на информација за природата на својата здравствена состојба и очекуваниот исход од предложените или преземените медицински интервенции, освен во случаите во кои мора да биде свесен за природата на својата болест, за да не го загрози здравјето на другите?.

Право на учество во одлучувањето - Ова право го опфаќа правото на информираност и правото на прифаќање или одбивање на определена медицинска интервенција. Ова право може да биде ограничено само кога тоа е оправдано со здравствената состојба на пациен- 
тот, во случаи и на начин уреден со Законот.

Право на прифаќање и одбивање на определена медицинска интервенција - Прифаќањето или одбивањето на определена медицинска интервенција, како пациент, се изразува со потпишување на изјава на образец кој ќе го даде здравствената установа, освен во случаите на медицински интервенции чиешто одложување или непреземање би го загрозило или би предизвикало привремено или трајно оштетување на здравјето, односно здравјето на други лица. За пациент кој не е при свест, за пациент кој е примен во здравствена установа без негова согласност, за деловно неспособен и за малолетен пациент, изјавата ја потпишува родителот, законскиот застапник, односно старателот ${ }^{7}$.

Во студијата со анкетното истражување на пациентите е анализирана имплементацијата на правата на пациентите во пракса, а во овој труд се прикажани резултатите од имплемтацијата на две права на пациенти, и тоа: право на информираност за препорачаните медицински интервенции и право на прифаќање и одбивање на определена медицинска интервенција.

Информација за правото на информираност за препорачаните медицински интервенции имале мнозинството $(85,2 \%)$ од анкетираните пациенти, а $72,1 \%$ имале лично искуство со ова право. Информација за правото на прифаќање и одбивање на определена медицинска интервенција имале $77 \%$ од анкетираните пациенти, а само 32,8\% имале лично искуство со користењето на ова право.

\section{Заклучок}

Република Македонија како кандидат за членство во Европската Унија работи на подобрување на човековите права, со посебен фокус на подобрување на човековите права во здравствената заштита. Човековите права во здравствената заштита во Република Македонија се рефлектирани во националната легислатива, и со ратифицарините и потпишани меѓународни инструменти.
Споредбата помеѓу правата на пациентите во Република Македонија и правата на пациентите во Европската повелба покажува дека во националната законска рамка суштински се застапени сите права на пациентите кои се содржани во Европската повелба.

Легислативната рамка во Република Македонија опфаќа една целина во сферата на заштита на правата на пациентот, каде што на пациентот му се загарантирани законски права во процесот на лекувањето кои ќе му обезбедат почитување и заштита на неговата личност и интегритет и е хармонизирана со европската легислатива.

Резултатите од истражувањето со пациентите покажуваат дека легислативата за правата на пациентите во Република Македонија релативно се имплементира во пракса кај пациентите.

Затоа е потребно е да се работи на подобрување на имплементација на правата на пациентите во пракса, подигнување на свеста на граѓаните за познавање на правата на пациентите и поттикнување на медицинскиот персонал за почитување на правата на пациентите и нивна задолжителна примена во пракса

\section{Референци:}

1. 1.1 Устав на Светска здравствена организација. Достапно на: http://www.who.int/governance/ eb/who_constitution_en.pdf, Посетено на 04.05.2018

2. Караџинска Бислимовска Ј. и сор. Човековите права во здравствената заштита: прирачник за практичари: Скопје: Медицински факултет; ЦРИС Студиорум, 2010

3. Закон за здравствена заштита Службен весник на Република Македонија 6р. 43/2012, 145/2012, 87/2013, 164/2013, 39/2014, 43/2014, 132/2014, 188/2014, 10/2015, 61/2015, 154/2015, 192/2015, 17/2016, 37/2016

4. European Charter of Patient Rights. Достапно на: http://ec.europa.eu/ health/ph_overview/co_operation/ mobility/docs/health_services_ co108_en.pdf Посетено на 


\subsubsection{8}

5. Universal Decalaration for Human Rights. Достапно на: http://www. ohchr.org/EN/UDHR/Documents/ UDHR_Translations/eng.pdf посетено на 15.05.2018

6. Устав на Република Македонија. Собрание на Република Македонија. Скопје, 1991

7. Закон за заштита на правата на пациентите. Службен весник на $\mathrm{Pe}$ публика Македпнија бр.82/2008, 12/2009, 53/2011

8. Закон за здравствено осигурување. Службен весник на Република Македонија бр. 25/2000, 96/2000, 50/2001, 11/2002, 31/2003, 84/2005, 37/2006, 18/2007, 36/2007, 82/2008, 98/2008, 6/2009, 67/2009, 50/2010, 156/2010, 53/2011, 26/2012, $16 / 2013$

9. Закон за јавно здравје. Службен весник на Република Македонија бр. 22/2010, 136/2011

10. Закон за ментално здравје. Службен весник на Република Македпнија бр. 71/2006

11. Advancing Human Rights in Patient Care: The Law in Seven Transitional Countries. Достапно на: https:// www.opensocietyfoundations. org/sites/default/files/Advancing$\mathrm{H} \mathrm{u}$ m a n - Righ t s - in - Patien tCare-20130516.pdf Посетено на 30.06.2018

12. Patient's Rights Act, 1996. Достапно на:http://www.iracm.com/wpcontent/uploads/2013/01/loi-surles-brevets-1996-anglais-3539.pdf Посетено на 31.05. 2018

13. Health and Human Rights Resource Guide. Open Society Institute, 2013 Достапно на: https://cdn2. sph.harvard.edu/wp-content/ uploads/sites/25/2014/06/HHRRG_ Introduction.pdf Посетено на: 31.03.2018

14. Charter of Fundamental Rights of the European Union. Достапно на: http://www.europarl.europa.eu/ charter/pdf/text_en.pdf Посетено на 01.06.2018г.
15. European Social Charter (ESC). Достапно на: https://www.coe.int/en/ web/turin-european-social-charter Посетено на 01.06.2018

16. Health Rights: Human Rights in Patient Care Home Page. Достапно на: www.health-rights.org Пристапено на 31 март 2018

17. Convention on the Rights of the Child (CRC).United Nations (UN) General Assembly Reso-lution 44/25. November 20, 1989

18. Convention on the Elimination of All Forms of Discrimination against Women (CEDAW). UN General Assembley, New York, 18 December 1979

19. Convention on the Rights of Persons with Disabilities (CRPD). UN General Assembly Reso-lution. December 13, 2006

20. International Covenant on Economic, Social and Cultural Rights (ICESCR). United Nations General Assembly Resolution 2200A[XXI]. December 16, 1966

21. Pecelj G., Tozija F., Hajiof S. Health Care System in Transition profile (HIT) on The Former Yugoslav Republic of Macedonia. Observatory. 2000

22. The former Yugoslav Republic of Macedonia Health system review. Observatory. Health Systems in Transition Vol. 8 No. 22006

23. Lazarevik V. Policy Interventions to Tackle Health Inequalities in Macedonia: Patient rights and reference pricing of pharmaceuticals. Macedonian J of Med Sci. 2010; 3(1):57-60.

24. The former Yugoslav Republic of Macedonia Health system review. Health Systems in Tran-sition. Observatory 2017;19 (3)

25. European

Commission. Enlargement: Candidate countries. FYR Macedonia-Country profile. Достапно на: https://ec.europa. $\mathrm{eu} /$ neighbourhood-enlargement/ countries/detailed-countryinformation/fyrom_en Посетено 
на 31.05. 2018

26. Conclusions on the former Yugoslav Republic of Macedonia. In Communication from the Commission to the European Parliament and the Council "Enlargement Strategy and Main Challenges 2011-2012. COM 2011:666 final.

27. Human Rights in Patient Care: Practitioner Guides. Достапно на: http://cop.health-rights.org/ PractitionerGuides Посетено на 01.08.2018

28. European Convention on Human Rights. Council of Europe. Достапно на http://www.echr.coe.int/ Documents/Convention_ENG.pdf Пристапено на 11.08. 2018.

29. Таири М., Тозија Ф., Адеми В. Легислативната рамка за правата на пациентите во Република Македонија.. MEDICUS. ISSN 1409-6366 UDC 61 Vol 22 (2) 2017: 230-237

30. Извештај за спроведување на законот за заштита на правата на пациентите со фокус на механизмите за заштита на правата на пациентите. ЕСЕ. Скопје,2013

31. International Covenant on Civil and Political Rights. United Nations General Assembly Res-olution 2200A [XX1]. 16 December 1966

32. Charter on the Right to Health. International Union of Lawyers. UIA General Assembly. 31 August 2005

33. Declaration on the Rights of the Patient. World Medical Association. WMA Assembly Sep-tember/ October 1981 